\title{
Some relationships between lithology, basin form and hydrology: a case study from the Thames basin, UK
}

\author{
J. P. Bloomfield, ${ }^{*}$ S. H. Bricker ${ }^{2}$ and A. J. Newell ${ }^{1}$ \\ ${ }^{1}$ British Geological Survey, Maclean Building, Crowmarsh Gifford, Wallingford Oxfordshire, OX10 8BB, UK \\ ${ }^{2}$ British Geological Survey, Kingsley Dunham Centre, Keyworth, Nottingham NG12 5GG, UK
}

\begin{abstract}
The role of lithology in influencing basin form and function is explored empirically by investigating correlations between a range of catchment variables, where the spatial unit of analysis is not surface catchments but lithologically coherent groundwater units. Using the Thames basin, UK, as a case study, nine groundwater units have been identified. Values for 11 hydrological and geomorphological variables, including rainfall, drainage density, Baseflow Index, aquifer porosity, storage coefficient and log-hydraulic conductivity, aquifer and drainage elevation, river incision, and hypsometric integral have been estimated for each of the groundwater units in the basin, and Pearson correlation coefficients calculated for all pairs of variables. Seven of the correlation coefficients are found to be significant at a confidence level of $>99 \%$. Negative correlations between drainage density and log aquifer hydraulic conductivity, and between drainage density and river incision, and positive correlations between log-hydraulic conductivity and river incision, log-hydraulic conductivity and Baseflow Index, and between Baseflow Index and river incision are inferred to have consistent causal explanations. For example, incision of rivers into aquifers leads to relative increases in hydraulic gradients in the vicinity of rivers which, in turn, promotes the development of secondary porosity increasing both aquifer hydraulic conductivity and, hence, Baseflow Index. The implication of this interpretation is that the geomorphological evolution of basins is intimately linked to the evolution of hydraulic conductivity of the underlying aquifers. This is consistent with, and supports the notion of a coupled complexly evolving surface water-groundwater system.
\end{abstract}

\section{INTRODUCTION}

Understanding of catchment process is usually developed through studies at borehole, site, and riverreach scales. Studies at these scales commonly reveal characteristic site-specific processes, but the transfer of process understanding gained at one site to other often unmonitored sites, and up-scaling of processes understanding from the site to basin scale remains problematic (McDonnell et al., 2007; Tetzlaff et al., 2008). In addition, the distribution of hydrological data is typically patchy at the basin scale, being collected by a wide range of authorities and organisations for a variety of reasons to a range of standards, and it is often difficult to reconcile and use in a consistent manner (Soulsby et al., 2008). Even though it is difficult to represent hydrological complexity in a meaningful way at the basin scale, recent studies have suggested that it may be possible to simplify conceptualisations of basins while retaining some ability to understand and predict their hydrological behaviour, and that lithological mapping and classification schemes may provide a useful framework in this context (Devito et al., 2005; McDonnell et al., 2007).

Like other natural systems, the terrestrial water cycle is an open system that is highly heterogeneous. It exhibits non-linear processes and system feedbacks over a wide range of temporal and spatial scales. A number of workers have called for new approaches to understand and model this complexity through the development of unifying systems of basin classification (McDonnell and Woods, 2004; Wagener et al., 2007). Others have proposed developing a new vision for hydrology by exploring the organising principles that might underlie basin heterogeneity and complexity (Sivapalan, 2005; McDonnell et al., 2007; Tetzlaff et al., 2008). As part of this ongoing debate, there is an explicit recognition of the importance of the form of basins, how and why they have specific geomorphological characteristics, how these characteristics relate to the geological structure and basin evolution, and how this determines hydrological functions (Devito et al., 2005; Sivapalan, 2005; Phillips, 2006; Murray and Fonstad, 2007; Wagener et al., 2007). 
It has been known for a long time that, in addition to other factors such as climate and tectonism, lithology influences a range of geomorphological characteristics of basins, including drainage density (Carlston, 1963; Wilson, 1971; Tandon, 1974; Gregory and Gardiner, 1975; Abrahams, 1984; Kelson and Wells, 1989) and drainage gradients (Wilson, 1971; Lifton and Chase, 1992; Chen et al., 2003), and more recently, lithology, has also been identified as a factor that influences topographic relief and basin hypsometry (Lifton and Chase, 1992; Hurtrez and Lucazeau, 1999, Chen et al., 2003; Walcott and Summerfield, 2008), and dissection patterns (Luo and Stepinski, 2008). In addition, although also long-recognized (Toth, 1963), the importance of bedrock lithology on the configuration of the water table and large-scale groundwater flow systems at the basin scale has recently been reaffirmed (Toth, 1999; Winter, 2001; Devito et al., 2005; Dahl et al., 2007; Bloomfield et al., 2009).

In many of these studies, the influence of lithology on basin characteristics has usually been assessed in a semi-quantitative manner by correlating it, typically as a categorical variable, with other geomorphological or hydrological variables. Elsewhere, lithology is invoked to explain qualitatively the differences in correlations between geomorphological or hydrological variables or deviations from such correlations. In this context, the term 'lithology' is used as a surrogate for other variables. For example, some workers have suggested that lithology is important in landscape evolution due to differences in 'erodability' (Lifton and Chase, 1992), while other workers have emphasized relationships between rock 'permeability' and runoff generation and drainage density (Carlston, 1963; Wilson, 1971; Abrahams, 1984; Kelson and Wells, 1989).

To begin to understand more fully the role of lithology in influencing basin form and functions there is a need to establish more quantitative correlations between lithological variables, and geomorphologcal and hydrological variables. Inspired by the renewed interest in relationships between the geological characteristics of basins, basin-scale hydrological processes, and basin geomorphology (Devito et al., 2005), the overall aim of this empirical study is to investigate and quantify relationships between aspects of basin-scale lithological variation, aquifer and surface water characteristics, and features of basin geomorphology. Specifically, we aim to test the hypothesis that the evolution of features of the land surface and the underlying aquifers are linked, and that the nature of this co-evolution is a function of lithology. To do this, rather than using surface water catchments as the basic spatial unit for analysis, areas of common lithology, referred to here as groundwater units, are used to explore the relationships between land surface and aquifer characteristics. If linkages between lithology, geomorphological, surface flow, and groundwater characteristics can be established empirically then this potentially opens up the possibility of using lithological mapping to help estimate features of flow in ungauged catchments.

This approach, of using a continuous mapping of a catchment characteristic to investigate relationships between landscape and hydrological variables, is similar to the 'hydrology of soil types' (HOST) classification that the Institute of Hydrology developed to estimate flow duration and flow frequency parameters (Gustard et al., 1992; Boorman et al., 1995). HOST consists of a grouping of soil associations into classes based on physical properties of soils and on their hydrogeological setting. As well as being used to model and predict flow duration and frequency, multivariate regression of HOST data against Baseflow Index data for representative catchments in the UK produced continuous Baseflow Index catchment characteristics referred to as BFIHOST (Gustard et al., 1992; Boorman et al., 1995). Since Bloomfield et al. (2009) have shown that similar regression models based on groundwater units can be used to predict Baseflow Index, this provides support for the idea that groundwater units could be used to search for empirical relationships between lithology and other basin parameters.

The Thames basin, UK, has been used as a case study. It was chosen because it is possible, as a first approximation, to assume that any variation in geomorphological and aquifer characteristics across the basin is primarily a function of lithological variations, and that the effects of variations in climatic and tectonic factors on geomorphological and aquifer characteristics of the basin is only secondary. Following an overview of the geology and geological evolution of the Thames basin, a simplified hydrostratigraphy is developed and parameterized. Some empirical measures of geomorphological 
and hydrological features of the basin are then determined, based on a mapping of the hydrostratigraphy across the basin, and correlations between these geomorphological, hydrological, and aquifer variables are investigated. Interdependencies between groundwater, hydrological, and geomorphological processes at the basin scale are highlighted, and the results are discussed in the context of the evolution of the basin.

\section{THE THAMES BASIN STUDY AREA}

The Thames basin, defined by the catchment of the River Thames and its tributaries, is situated in the southeast of the UK (Figure 1). For the purposes of this study the Thames basin is defined by the Environment Agency's Thames River basin District (Environment Agency, 2009). The source of the River Thames is in the Cotswolds in Gloucestershire. The length of the river down to Teddington Lock in west London (the lowest flow gauging station on the River Thames that is sited at the nontidal limit of the river) is approximately $235 \mathrm{~km}$, and the area of the basin is about $16100 \mathrm{~km} 2$. Mean annual rainfall varies across the Thames basin from about 600 to $900 \mathrm{~mm}$ with a typical value of annual effective rainfall of $3 / 4250 \mathrm{~mm}$. The effective rainfall is limited over the summer months and peaks in the winter months at approximately $60 \mathrm{~mm} / \mathrm{month}$. The mean flow at Teddington Lock is about 78 m3s_1 (Natural Environment Research Council, 2008).

The western parts of the Thames basin are predominantly rural, whereas, the highly urbanized area of Greater London is located in the central and eastern part of the basin and is home to about 14 million people. Just over $40 \%$ of public water supplies in the basin, equivalent to $3 / 42 Đ 25$ million m3/d, come from groundwater, mainly from the Chalk aquifer. Although there have been extensive studies of the hydrogeology of the basin, with only a few exceptions (Andrews, 1962; Bloomfield et al., 2009), these studies have been at the site, river reach, or catchment scale with individual aquifers, catchments, or river reaches usually the focus of investigations. A reason for the paucity of basin-wide groundwater studies in the Thames basin is that at larger scales, like other basins, the geology and hydrogeology of the basin becomes formidably complex.

\section{Geological structure, geomorphology and basin evolution}

The Thames basin is centred on a broad, shallow, synclinal fold which opens to the east, known as the London basin (Figure 2). The syncline has a sinuous northeast trending axis and is cored by Tertiary clays and sands which reach a maximum thickness of $320 \mathrm{~m}$ around Bagshot in Surrey (Figure 2) (Sumbler, 1996). The northern limb of the fold dips uniformly to the southeast generally at an angle of less than $1 \square$ while the southern limb has greater structural complexity with highly variable dips up to $55 \square$ Which produce a marked variation in the width of the Chalk outcrop along the North Downs. The greater structural complexity in the southern part of the Thames basin reflects the presence of underlying west-east trending basement faults which form the northern boundary of Mesozoic Weald basin (Figure 2) (Sumbler, 1996; Underhill and Stonely, 1998). North-directed compression during the Tertiary inverted the Weald basin to form the Weald Anticline, elevating a core of Early Cretaceous sands, which form the southeastern limit of the Thames basin, and producing locally steep folding in the Chalk of the North Downs above reactivated faults (Butler and Pullan, 1990). The northern part of the Thames catchment is underlain by the London Platform, a concealed elevated block of Palaeozoic basement which has steep faulted margins with the Weald, Pewsey and Worcester basins along its southern and western limits (Figure 2) (Busby and Smith, 2001). Strata overlying the London Platform and northsouth trending Worcester basin were largely unaffected by Tertiary compression and are dominated by three southwest-northeast trending carbonate ridges which dip at low angles toward the southeast (Figure 2), the Middle Jurassic Inferior/Great Oolite of the Cotswolds, the Late Jurassic Corallian Group, and the Cretaceous Chalk Group of the Berkshire Downs and Chilterns. These carbonate units range up to about $200 \mathrm{~m}$ thick, although the Corallian sandstones and limestones are thinner and laterally impersistent. Each gently inclined carbonate sheet has a steep northern scarp and a gentle dip slope dissected by predominantly southeast flowing streams and dry valleys where the more heavily incised valleys have flowing river sections. The dipslope rivers are typically bournes with intermittent upper reaches and migrating sources associated 
with seasonal changes in groundwater heads. These valleys commonly show a strong rectangular or linear development reflecting the control of fracture sets on river erosion. The main carbonate units are separated by thick Jurassic and Cretaceous marine mudstone formations which have been preferentially eroded by strike parallel (southwestnortheast) rivers. The southern part of the Thames basin includes the Chalk ridge of the North-Wessex Downs connected via four incised rivers to the siliciclastic dominated sandstones and mudstones of the Cretaceous Lower Greensand and Wealden groups.

The geological evolution (Jurassic to the present) of the Thames basin can be characterized by the two main events which have shaped the geology of the catchment (Underhill and Stonely, 1998):

(1) Tectonic extension and basin subsidence in the Jurassic and Cretaceous during which time the major carbonate and siliciclastic aquifers were deposited. Marked contrast in the subsidence history of the London Platform and the surrounding Weald-Pewsey- Worcester basins had an important control on the distribution and thickness of Early Cretaceous Wealden Group and Lower Greensand aquifers in the Thames basin.

(2) A Tertiary and Quaternary sedimentary record marked by long stratigraphic gaps between depositional events. Aquifers were subject to uplift, weathering and erosion under episodes of tectonic compression and regional uplift and fluctuating climate and seal level.

Evidence from raised Neogene marine deposits (Crag Group/Lenham Formation) and Thames River Terrace Gravels suggests that up to $200 \mathrm{~m}$ of uplift may have occurred during the Quaternary across the basin as a whole, and affecting both the London basin and the Wealden Anticline (Jones, 1999; Maddy et al., 2000). The timing and magnitude of this uplift suggests that the Thames basin may have been eroded to its present form only in the last 600000 years. This seems feasible given the high rates of fluvial erosion and mass wasting that could have occurred under Quaternary periglacial conditions (Goudie, 1990). The products of Quaternary periglacial processes are seen today in the partial cover of river terrace gravels, glacial tills, solifluction deposits, and weathered residuals that partially cover the bedrock geology.

\section{METHODS}

As noted in the introduction, we have adopted a simple empirical approach in order to investigate lithological controls on features of basin geomorphology and hydrology and the co-evolution of the land surface and underlying aquifers. Groundwater units have been used as the basic spatial unit of analysis. The identification of appropriate groundwater units is based on considerations of the hydrostratigraphy of the Thames basin. Those units and their parameterisation are described below. Because we are interested in first-order correlations we have made a number of simplifying assumptions. Each geological unit is parameterized with a representative, often mean, value. Consequently, it is not possible to take into account the effect of within-unit complexity on correlations between the parameters. Scaling relationships between the variables have not been considered even though it is acknowledged that scaling of many features of river basins is ubiquitous (Rodriguez-Iturbe and Rinaldo, 1997; Dade, 2001). As a consequence, it is not possible to make any inferences relating to the scaling characteristics of any of the correlations between variables described in the following sections. Finally, we recognize that basins are not simply a collection of paths, but represent a strong downstream organisation where downstream changes in elevation or incision can be related to changes in upstream morphology and flows. Given the simple approach that we have adopted, interpretation of the results in the context of interactions between upstream and downstream features of the basin is difficult as the analysis does not represent dynamic processes, relationships, or feedbacks across the basin.

Development of a hydrostratigraphy for the basin 
The British Geological Survey’s 1 : 250000 digital solid geology mapping has been used in a heuristic manner to define groundwater units for the Thames basin that closely follows the description of the gross geological structure of the basin (Figure 2). The 1: 250000 mapping consists of 64 bedrock and 10 superficial geological units. To define the simplified groundwater units, stratigraphically neighbouring formations and groups have been combined where possible on the basis of the following simple assumptions. Recognized groundwater flow systems (Allen et al., 1997) were taken into account when developing the hydrostratigraphy, such that where two geological units were known to be in hydraulic continuum they were grouped together. In this way, the Thanet Sand Formation, for example, is grouped with the underling Chalk aquifer rather than with other Palaeogene deposits. Bloomfield et al. (2009) used a similar approach to develop a hydrostratigraphic classification scheme to model lithological controls on Baseflow Index. Since the outcrop of the groundwater units are used as the areas for the following analysis, a key consideration in the development of the hydrostratigraphy was the spatial continuity of the units. Consequently, it was necessary to merge some minor aquifers with less productive units where the minor aquifers had limited outcrops or were spatially impersistent. So, for example, the Coralline Group, and Portland and Purbeck limestones were merged with the more persistent, clay-dominated Ancholme Group to form the Upper Jurassics unit, and the Bracklesham Group and the Bagshot Formation containing silt and sandstones were merged with the London Clay to form the Thames unit. Diamicton, an unconsolidated glacial till with significant clay fraction found in the northeast of the basin is the only superficial deposit to be included in the hydrostratigraphy. Diamicton is included because it is the thickest and most continuously extensive superficial deposit in the basin. It is relatively impermeable and has been inferred to exert a significant control on run-off and drainage (Bloomfield et al., 2009) as well as potentially effecting recharge processes to the underlying Chalk aquifer. Other superficial deposits such as sands and gravels, alluvium, and Clay-with-Flints have not been included as they are not continuous over large areas of the basin and not easily amenable to spatial analysis at the basin scale, although it is acknowledged that they may be locally hydrogeologically significant. The resulting hydrostratigraphy, described in Table I, consists of nine groundwater units. Figure 3 shows their spatial distribution across the basin.

\section{Parameterisation of the groundwater units}

Eleven geomorphological, surface water and aquifer variables, Table II, have been estimated for each of the groundwater units described in Table I. The variables include: mean age of each groundwater unit (included as the age of sedimentary rocks has previously been related to their maximum burial or overburden depth and so may relate to the matrix porosity of the groundwater units, Bloomfield, 1997), average elevation of the groundwater unit, average river elevation within the unit, a representative hypsometric integral (based on the largest contiguous area of outcrop for each groundwater unit in the basin, and calculated using the approximation of Pike and Wilson, 1971, where hypsometric integral is given by (elevation mean $\left._{\text {- elevation }} \min \right) /\left(\right.$ elevation $_{\max }$ - elevation $\left.{ }_{\min }\right)$ for a given area), drainage density, river incision (where river incision is defined as the difference between the mean unit elevation and the mean elevation of rivers on that unit), long-term annual average rainfall, and representative values of Baseflow Index. Aquifer and drainage mean elevations and drainage density are derived from a digital terrain model with a 5-m-spatial resolution and plus or minus $1 \mathrm{~m}$ vertical accuracy and a mapping of the drainage network (where mapping of the drainage network is at a scale consistent with the underlying geological mapping) (Morris and Flavin, 1990; 1994; Moore et al., 1994). Table II also shows representative values, matrix porosity, hydraulic conductivity, and storativity. Values for the aquifer variables in Table II come from three sources. They are either based on data from British Geological Survey's Aquifer Properties Database (Allen et al., 1997), on data from the grey literature associated with specific hydrogeological investigations in the basin, or on book values for equivalent generic lithologies. Details of the data sources are given in Table II.

\section{RESULTS}


Pearson correlation coefficients have been calculated to test for correlations between pairs of variables. Table III shows the correlation coefficients for pairs of geomorphological, surface water and aquifer variables. Values in parenthesis after each coefficient are the probability that the correlation is 0 , i.e. where this probability is small then the value of the Pearson correlation coefficient is significant. All pairs where there is a significant (at $>99 \%$ probability) correlation of greater than $0 Đ 80$ or less than_0Đ80 are highlighted in bold. Figure 4 is the corresponding scatter plot matrix for all pairs of the eleven variables showing the degree of linearity in the correlations between the pairs of variables. Note that it is not an a priori assumption that a high degree of correlation between any pair of variables in Table III is necessarily due to a causal relationship, and given the unconstrained uncertainties associated with the values of the different variables in Table II, Table III is not intended as the starting point for a rigorous statistical analysis. Rather, the correlations are used in the following as the basis for a discussion of the nature and controls on relationships between geomorphological, surface water and groundwater factors at the basin scale.

On the basis of the assumption that correlations with a significance level of $>99 \%$, Table III highlights 7 significant correlations. Are any of them reasonably attributable to causal relationships, and if so, do these causal relationships provide any insights into lithological controls on basin hydrology or form? Table III shows that mean groundwater unit elevation and mean river elevation are strongly correlated (correlation coefficient of 0Đ831) as would be expected as these variables are closely related so no causal relationship is inferred, but what about the other 6 significant correlations?

Table III shows a significant negative correlation (_0Đ811) between log-hydraulic conductivity, HC, and drainage density, while the scatter plot, Figure 4, shows a good linear relation between the two variables. A linear regression through the data has the form:

Drainage density _km/km2_ D_0Đ138 ð $\log 10$

hydraulic conductivity (m/s) with an R2 of $0 Đ 98$.

Although previous studies have inferred or attributed significant variations in drainage density to differences in lithology across a range of geological settings (Carlston, 1963; Wilson, 1971; Tandon, 1974; Kelson and Wells, 1989), this is the first time that representative values of hydraulic

conductivity for lithologies at the basin scale have been related quantitatively with drainage density. It should be expected that the ratio of total surface run-off to groundwater recharge will be greater for lithological units that are relatively impermeable than those that have higher effective hydraulic conductivities. If all other factors are constant, for relatively impermeable units there should be a tendency either for relatively higher surface flows on drainage networks of a similar density or for higher drainage densities. However, for the former to occur precipitation must find a way to reach the drainage network, and, in the absence of pervasive overland flow, channels must form.

A related correlation (Table III) is the inverse correlation (__0Đ806) between drainage density and river incision. This too is inferred to have a simple causal explanation. If all other factors are constant, for a given total surface run-off stream power will be greater per unit length of stream in groundwater units with lower drainage density. This in turn should enhance erosion of the stream bed for bedrockor other detachment-limited rivers (Whipple et al., 2000). As the groundwater units used in the analysis are predominantly bedrock aquifers (with the exception of the Diamicton, a glacial till deposit in the northeast of the basin, Table I and Figure 3) this provides a reasonable causal explanation for the correlation. Unconsolidated superficial deposits are found throughout the river valleys of the Thames basin, and in the lower Thames valley the alluvium may be up to tens of metres thick in the vicinity of the main river channel. Incision or aggradation of river channels dominated by unconsolidated alluvial deposits, such as those found in the lower Thames, are controlled by a delicate balance between sediment supply and transport capacity. So, although for unconsolidated deposits increased stream power may not provide an adequate simple causal explanation for the correlation between drainage density and incision, because the correlation has been established for all the groundwater units defined in Table I, and because these units are inferred to be dominated by bedrock rivers, the relationship between drainage density and incision holds. This interpretation is supported 
by the observation that the values of incision for both Diamicton and the Thames groundwater units, the latter covering the lower Thames, are relatively low when compared with those expected based on a linear regression through incision against drainage density data for the other groundwater units.

Incision is also significantly correlated with hydraulic conductivity (0Đ91) and with Baseflow Index (0Đ861). Are these correlations consistent with causal relationships? It is possible to infer a direct causal relationship between incision and hydraulic conductivity associated with aquifer development. If all other factors are constant, incision of rivers into aquifers will lead to increased hydraulic gradients between the river valleys and the groundwater divides. These increased hydraulic gradients may promote the development of, or enhance pre-existing, secondary fracture and/or matrix porosity. For example, the concept of focussed flow towards river valleys driving the development of secondary porosity through dissolution of carbonate aquifers or cements, was developed by Rhoades and Sinacori (1941) and more recently used by Price (1987) and Price et al. (1993) to explain the development of secondary fracture porosity in the Chalk (the major aquifer in the Thames basin). The development of secondary porosity associated with river incision is consistent with increased hydraulic conductivity and, hence, consistent with the observed strong correlation between hydraulic conductivity and incision. Any enhanced secondary porosity due to incision would also have the effect of tending to increase baseflow and, hence, contribute to the good correlations between incision and BFI, and between hydraulic conductivity and Baseflow Index (correlation coefficient 0Đ888). Bloomfield et al. (2009) have previously explained a strong causal relationship between hydraulic conductivity and BFI at the basin scale, and the findings of this study are consistent with that previous work.

The last remaining significant correlation in Table III, the correlation between Baseflow Index and aquifer elevation (correlation coefficient 0Đ802) cannot be so easily explained, and no causal relationship is inferred. The parameters are not directly related in any way and there is no simple or obvious causal relationship to explain this correlation. It happens that the older, more permeable aquifer units (such as the Jurassic limestones and the bulk of the Chalk outcrop) tend to lie in the more elevated western part of the Thames basin, whereas the younger, and generally less permeable, units (such as the Thames unit) tend to outcrop in the much lower lying eastern part of the basin. This may explain, in large part, the correlation.

Matrix porosity and storativity do not show significant correlations with any of the variables in Table III. There is a weak but insignificant inverse correlation between porosity and age of the units. As older units may be expected to have lower porosities than younger units, since they are more likely to have been subjected to a greater overburden and, hence, compaction (Bloomfield et al., 1995; Bloomfield, 1997), it is inferred that there may be a high degree of uncertainty associated the values of mean porosity in Table II. Storativity is a function of release of water from both the matrix and from fractures. Consequently, the degree and nature of fracturing of the units, particularly near the water table, is important in influencing storativity. As fracturing of the units does not have a simple correlation with maximum depth of burial, the lack of any correlation between storativity and the age of the units is to be expected. The absence of correlations between storativity and any of the other parameters is consistent with the inference that fracture style and intensity has not been resolved in any meaningful way by the present classification scheme for the groundwater units, but also probably reflects a relatively high degree of uncertainty in the values of storativity in Table II.

Although Marani et al. (2001) demonstrated that groundwater rating curves should reflect some of the geomorphological characteristics of catchments, such as the hypsometric distribution of the analysed region, and Vivoni et al. (2008) demonstrated that the ratio of surface to subsurface runoff was a function of catchment hypsometry, Table III shows that the hypsometric integral for each lithological unit does not correlate significantly with any of the other variables. The hypsometric integrals used in the present study were based on areas defined by the largest contiguous outcrop of each groundwater unit. In all cases, these contiguous groundwater units cut across a number of topographically defined catchments. The hypsometric integrals calculated in this manner appear not to be a meaningful measure of the topographic characteristics of the groundwater units and other more appropriate ways 
of describing the topographic characteristics of the lithologically defined areas need to be sought if relationships between groundwater units and topography are to be explored further.

\section{DISCUSSION}

It was noted in the introduction that the Thames basin was chosen as it had been assumed that, to a first approximation, variations in the geomorphological, surface water, and groundwater characteristics of the basin were primarily a function of lithological variations rather than climatic or tectonic factors. Table III shows that rainfall is not strongly correlated with any of the other parameters in the study. This may be due to a combination of the limited relief across the basin and the dominance of frontal (compared to relief) rainfall in the UK. The lack of correlation between rainfall and other parameters supports the assumption that precipitation is of secondary importance compared to lithological variation across the basin. In addition, as previously noted, the basin, as a whole, has been subject to a common tectonic uplift of the order of $200 \mathrm{~m}$ over the last 600000 years. Even though the tectonic histories of the Weald basin and the London platform up until the end of the Neogene followed different trajectories, throughout the Quaternary, both have undergone very similar uplift, river downcutting and periglacial weathering, and erosion. Although there is no reason to assume that the uplift was entirely homogeneous across the Thames basin, there are no documented large structures across the basin with large differential uplift histories over the last 600000 years. So the assumption that tectonic variability across the basin is a second-order factor compared with lithological variation also appears to be substantiated.

Basing on the very simple analysis of the correlation coeffcients in Table III it is clear that hydraulic conductivity, rather than porosity and storage, is the key lithological descriptor when searching for meaningful (causal) correlations with other basin-wide parameters. In particular, a strong inverse relationship between log-hydraulic conductivity and drainage density has been highlighted. This relationship could potentially be exploited to inform assessments of aquifer hydraulic conductivities in ungauged basins where information on the geology and drainage density are available. However, this would require a number of assumptions to be satisfied and a more refined calibration of the relationship. The inverse correlation between log-hydraulic conductivity and drainage density has been established for the Thames basin where it has been inferred that neither climate nor tectonic factors exert a first-order control on drainage density. If the correlation is to be used to deduce representative aquifer hydraulic conductivities in ungauged basins, it must be assumed that drainage density in the ungauged basins is primarily a function of lithological variation in those basins. To use the correlation between between log-hydraulic conductivity and drainage density to deduce a representative hydraulic conductivity for groundwater units in an ungauged catchment it would be necessary to use a correlation that has been calibrated for a lithostratigraphy that is similar to the ungauged catchment, and ideally, one that has been calibrated from a similar climatic zone and tectonic regime. The Thames basin, for example, does not contain crystalline basement rocks or extensive unconsolidated aquifers at outcrop so the correlation presented in the present study would not be suitable for use in modelling hydraulic conductivity in settings where such lithostratigraphies are dominant. Calibration of the relationship between log-hydraulic conductivity and drainage density across a range of contrasting lithostratigraphies where hydraulic conductivity distributions for the major lithologies are relatively well documented or constrained would provide a more robust basis for applying the relationship to ungauged catchments. Given an appropriately calibrated relationship and using surface drainage information it would be possible to estimate representative hydraulic conductivity for mapped lithological units in an ungauged basin. For basins where climate and tectonic factors are secondary, using continuous estimates of drainage density (Tucker et al., 2001; Luo and Stepinski, 2008) and lithological mapping over a range of scales may yield useful insights into the scaling of relationships between log-hydraulic conductivity and drainage density and, hence, aquifer hydraulic conductivity.

In a recent commentary article Devito et al. (2005) proposed a hierarchical schema describing a framework for the broad-scale classification of hydrologic response units that generalized the dominant controls on the water cycle (Devito et al., 2005, Table I). They proposed the following 
factors in order of importance: climate, bedrock geology, superficial geology, soil type and depth, and finally topography and drainage network. In particular, they emphasized the importance of contrasts in bedrock permeability in controlling 'continental-' to 'regional-scale' cycling of water. Devito et al. (2005) proposed that permeable bedrock strongly influences regional flow systems and suppresses the importance of topography in controlling surface flow, whereas impermeable bedrock tends to produce more local flow systems where topographic features exert more influence on surface flows. However, this schema (Devito et al., 2005) is static in terms of the evolution of the geomorphology and topographic form of basins, and although this static schema, and others like it such as those based on the groundwater flow systems model of Toth (1963, 1999), e.g. Dahl et al., (2007), is useful in highlighting the broad relationships between topography, surface flows, and groundwater flow, it does not appear to satisfactorily capture the dynamic relationships between landscape and aquifer development that have been inferred based on the results of the present study.

From the analysis of the results from the present study, it is clear that at the basin scale the geomorphological evolution of basins must be intimately related to the evolution of their hydrogeological structure. It can be inferred from the results of this study that hydraulic conductivity of the aquifers must play an important role during the early stages of landscape development following uplift, in establishing the drainage density, and hence, the potential for degree of river incision. This apparent close coupling between run-off generation, and landscape and aquifer evolution has to date been poorly described. For example, in the extensive review by Toth (1999) on the role of groundwater as a geological agent, regional gravity-driven groundwater flow was described and identified as the predominant mechanism that drives the disequilibria required to develop and maintain features such as springs and wetlands, but the concept of coupled land surface and aquifer evolution was not described. However, the close relationships between aquifer hydraulic conductivity, baseflow, drainage density, and river incision identified in Table III is consistent with and supports the notion of a coupled complexly evolving surface water-groundwater system that is beginning to be developed (Sivapalan, 2005; McDonnell et al., 2007; Tetzlaff et al., 2008).

\section{CONCLUSIONS}

Lithological controls on geomorphological and hydrological features of basins can be effectively investigated if climatic and tectonic variations in the basin are not significant, and if the areas for the analysis are based on lithological mapping rather than topographically defined surface catchments. It is necessary to develop an appropriate scheme to define the hydrostratigraphic units used in the analysis. To do this, some a priori knowledge of the hydrogeology of the basin is ideally required. The present study used an heuristic approach to define nine units, however, a statistical approach, such as that used by Bloomfield et al. (2009) could also be adopted. The hydraulic conductivity of aquifers, rather than porosity and storage, is the key lithological descriptor when searching for meaningful (causal) correlations with other basin wide variables. A strong inverse relationship between hydraulic conductivity and drainage density has been highlighted where, for the Thames basin, drainage density $(\mathrm{km} / \mathrm{km} 2)$ D_0Đ138 $\partial \log 10$ hydraulic conductivity $(\mathrm{m} / \mathrm{s})$. If this inverse relationship can be calibrated with sufficient precision for a range of representative lithostratigraphies, for basins where lithological factors dominate drainage density over and above climate and/or tectonic factors, then such relationships could potentially be used to inform assessments of aquifer hydraulic conductivities in ungauged basins.

Positive correlations between log-hydraulic conductivity and incision, log-hydraulic conductivity and Baseflow Index, Baseflow Index and incision, and a negative correlation between drainage density and incision are inferred to have a consistent causal explanation, and the implication of this is that at the basin scale the geomorphological evolution of basins must be closely coupled to the evolution of hydraulic conductivity in the underlying aquifers.

\section{ACKNOWLEDGEMENTS}


This paper is published with the permission of the Executive Director of the British Geological Survey

(Natural Environment Research Council).

\section{REFERENCES}

Abrahams AD. 1984. Channel networks: A geomorphological perspective. Water Resources Research 20(2): 161-168.

Allen DJ, Brewerton LJ, Coleby LM, Gibbs BR, Lewis MA, MacDonald AM, Wagstaff SJ, Williams AT. 1997. The physical properties of major aquifers in England and Wales. British Geological Survey Research Report WD/97/34, pp. 312.

Andrews FM. 1962. Some aspects of the hydrology of the Thames basin. Proceedings of the Institution of Civil Engineers, 21: 55-91.

Bloomfield JP. 1997. The role of diagenesis in the hydrogeological stratification of carbonate aquifers: An example from the Chalk at Fair Cross, Berkshire, UK. Hydrogeology and Earth System Sciences 1: 19-33.

Bloomfield JP, Brewerton LJ, Allen DJ. 1995. Regional trends in matrix porosity and dry density of the chalk of England. Quarterly Journal of Engineering Geology 28: S-131-142.

Bloomfield JP, Allen DJ, Griffiths KG. 2009. Examining geological controls on baseflow index (BFI) using regression analysis: An illustration from the Thames Basin, UK. Journal of Hydrology 373: 164-176.

Boorman DB, Hollis JM, Lilly A. 1995. Hydrology of soil types: a hydrologically-based classification of the soils of the United Kingdom. Institute of Hydrology Report No. 126.

Busby JP, Smith NJP. 2001. The nature of the Variscan basement in southeast England: evidence from integrated potential field modelling. Geological Magazine 138: 669-685.

Butler M, Pullan CP. 1990. Tertiary structures and hydrocarbon entrapment in the Weald Basin of southern England. Geological Society London: Special Publications; 55: 371-391.

Carlston CW. 1963. Drainage density and streamflow. USGS Geological Survey Professional Paper, 422-C.

Chen Y-C, Sung Q, Cheng K-Y. 2003. Along strike variations in morphometric feature in the Western Foothills of Taiwan: tectonic implications based on stream-gradient and hypsometric analysis.

Geomorphology 56: 109-137.

Dade WB. 2001. Multiple scales in river basin morphology. American Journal of Science 301: 60-73.

Dahl M, Nilsson B, Langhoff JH, Reefsgaard JC. 2007. Review of classification systems and new multi-scale typology of groundwater-surface water interaction. Journal of Hydrology 344: 1-16.

Devito K, Creed I, Gan T, Medoza C, Petrone R, Silins U, Smerdon B. 2005. A framework for broadscale classification of hydrologic response units on the Boreal Plain: is topography the last thing to consider? Hydrological Processes 19: 1705-1714.

Environment Agency. 2009. River basin management plan-Thames river basin district . Pub. Environment Agency: Bristol. Pp. 89.

http://wfdconsultation.environment-agency.gov.uk/wfdcms/en/thames/ Intro.aspx. 
Freeze RA, Cherry JA. 1979. Groundwater. Pub. Prentice-Hall: New Jersey.

Goudie AS. 1990. The landforms of England and Wales. Blackwell: Oxford.

Gregory KJ, Gardiner V. 1975. Drainage density and climate. Zeitschrift fur Geomorphologie 19(3): 287-298.

Gustard A, Bullock A, Dixon JM. 1992. Low flow estimation in the United Kingdom. Institute of Hydrology Report No. 108. ISBN 0948540451.

Hurtrez J-E, Lucazeau F. 1999. Lithological control on relief and hypsometry in the Herault drainage basin (France). Comptes Rendus l'Academie des Sciences - Earth and Planetary Sciences 328(10): 687-694.

Jones DKC. 1999. Evolving models of the Tertiary evolutionary geomorphology of southern England, with special reference to the Chalklands: Geological Society, London, Special Publications; 162: 123.

Kelson KI, Wells SG. 1989. Geologic influences on fluvial hydrology and bedload transport in small mountainous water sheds, Northwestern New Mexico, USA. Earth Surface Processes and Landforms 14: $671-690$.

Lifton NA, Chase CG. 1992. Tectonic, climatic and lithologic influences on landscape fractal dimension and hypsometry: implications for landscape evolution in the San Gabriel Mountains, California. Geomorphology 5: 77-114.

Luo W, Stepinski T. 2008. Identification of geologic contrasts from landscape dissection pattern: An application to the Cascade Range,Oregon, USA. Geomorphology 99: 90-98.

Maddy D, Bridgland DR, Green CP. 2000. Crustal uplift in southern England: evidence from the river terrace records. Geomorphology 33: 167-181.

Marani M, Eltahir E, Rinaldo A. 2001. Geomorphic controls on regional baseflow. Water Resources Research 37(10): 2691-2630.

McDonnell JJ, Woods RA. 2004. On the need for catchment classification. Journal of Hydrology 299: 2-3.

McDonnell JJ, Sivapalan M, Vache K, Dunn S, Grant G, Haggerty R, Hinz C, Hooper R, Kirchner J, Roderick ML, Selker J, Weiler M. 2007. Moving beyond heterogeneity and process complexity: A new vision for watershed hydrology. Water Resources Research 43: DOI:10.1029/2006WR005467. Moore RV, Morris DG, Flavin. 1994. Sub-set of UK digital 1 : 50000 scale river centre-line network. NERC, Institute of Hydrology; Wallingford.

Morris DA, Johnson AI. 1967. Summary of hydrologic and physical properties of rock and soil materials. U.S. Geological Survey Water Supply Paper 42.

Morris DG, Flavin RW. 1990. A digital terrain model for hydrology. Proc. 4th International Symposium on Spatial Data Handling. Vol. 1, Jul 23-27 Zurich, pp. 250-262.

Morris DG, Flavin RW. 1994. Sub-set of UK 50 m by 50 m hydrogeological digital terrain model grids. NERC, Institute of Hydrology; Wallingford. 
Murray B, Fonstad MA. 2007. Preface: Complexity (and simplicity) in landscapes. Geomorphology 91: 173-177.

Natural Environment Research Council. 2008. UK Hydrometric Register . Hydrological data UK series. Pub. Centre for Ecology and Hydrology. Pp. 210.

Phillips JD. 2006. Evolutionary geomorphology: thresholds and nonlinearity in landform response to environmental change. Hydrology and Earth System Sciences 10: 731-742.

Pike RJ, Wilson SE. 1971. Elevation-relief ratio, hypsometric integral, and geomorphic area-altitude analysis. Geological Society of America Bulletin 82: 1079-1084.

Price M. 1987. Fluid flow in the Chalk of England. In: Fluid flow in sedimentary basins and aquifers, Goff JC, Williams BP (eds). Special Publication of the Geological Society of London; 34: 141-156.

Price M, Downing RA, Edmunds WM. 1993. The Chalk as an aquifer. In: The hydrogeology of the Chalk of north-west Europe, Downing RA, Price M, Jones GP (eds). Clarendon Press: Oxford; pp. 11-34.

Reeves GM, Sims I, Cripps JC. 2006. Clay materials used in construction. Publication of the Geological Society: London. Rhoades R, Sinacori MN. 1941. Pattern of groundwater flow and solution. Journal of Geology 49: 785-794.

Rodriguez-Iturbe I, Rinaldo A. 1997. Fractal river Basins. Chance and self-organization. Pub. Cambridge University Press: Cambridge; pp. 547.

Sivapalan M. 2005. 13. Pattern, process and function: Elements of a unified theory of hydrology at the catchment scale. Encyclopedia of Hydrological Sciences, Anderson MG (ed), John Wiley \& Sons Ltd.: pp. 27. DOI: 10.1002/0470848944.hsa012.

Soulsby C, Neal C, Laudon H, Burns DA, Merot P, Bonell M, Dunn SM, Tetzlaff D. 2008. Catchment data for process conceptualization: simply not enough. Hydrological Processes 22: 2057-2061.

Sumbler, MG. 1996. British regional geology: London and the Thames Valley (4th edition). HMSO for the British Geological Survey: London.

Tandon SK. 1974. Litho-control of some geomorphic properties: an illustration from Kumaun Himalaya, India. Zeitschrift fur Geomorphologie 18(4): 460-471.

Tetzlaff D, McDonnell JJ, Uhlenbrook S, McGuire KJ, Bogaart PW, Naef F, Baird AJ, Dunn SM, Soulsby C. 2008. Conceptualizing catchment processes: simply too complex. Hydrological Processes 22: $1727-1730$.

Toth J. 1963. Mapping and interpretation of field phenomena for groundwater reconnaissance in a prairie environment, Alberta, Canada. International Association of Scientific Hydrology Bulletin 16(2):

20-68.

Toth J. 1999. Groundwater as a geologic agent: An overview of the causes, processes, and manifestations. Hydrogeology Journal 7: 1-14.

Tucker GE, Catani F, Rinaldo A, Bras RL. 2001. Statistical analysis of drainage density from digital terrain data. Geomorphology 36: 187-202. 
Underhill, J R, Stoneley R. 1998. Introduction to the development, evolution and petroleum geology of the Wessex Basin Geological Society, London, Special Publications 133: 1-18.

Vivoni ER, Di Benedetto F, Grimaldi S, Eltahir EAB. 2008. Hypsometric control on surface and subsurface runoff. Water Resources Research 44: W12502, DOI:10.1029/2008WR006931.

Wagener T, Sivapalan M, Troch P, Woods R. 2007. Catchment classification and hydrologic similarity. Geography Compass 1(4): 901-931.

Walcott RC, Summerfield MA. 2008. Scale dependence of hypsometric integrals: An analysis of southeast African basins. Geomorphology 96: 174-186.

Waters CN. 2008. Stratigraphical chart of the UK: Southern Britain. Pub. British Geological Survey: Keyworth, Nottingham. ISBN 978-0-751 8-3561-8.

Whipple KX, Hancock GS, Andreson RS. 2000. River incision into bedrock: Mechanics and relative efficacy of plucking, abraision, and cavitation. Geological Society of America Bulletin 112(3): 490503.

Wilson L. 1971. Drainage density. Length ratios and lithology in glaciated area of southern Connecticut. Geological Society of America Bulletin 82: 2955-2956.

Winter TC. 2001. The concept of hydrologic landscapes. Journal of the American Water Resources Association 37: 335-349. 


\section{Figures}



Figure 1. Map of the Thames basin showing the main topographic and drainage features. Greater London is shown by the grey ornament.

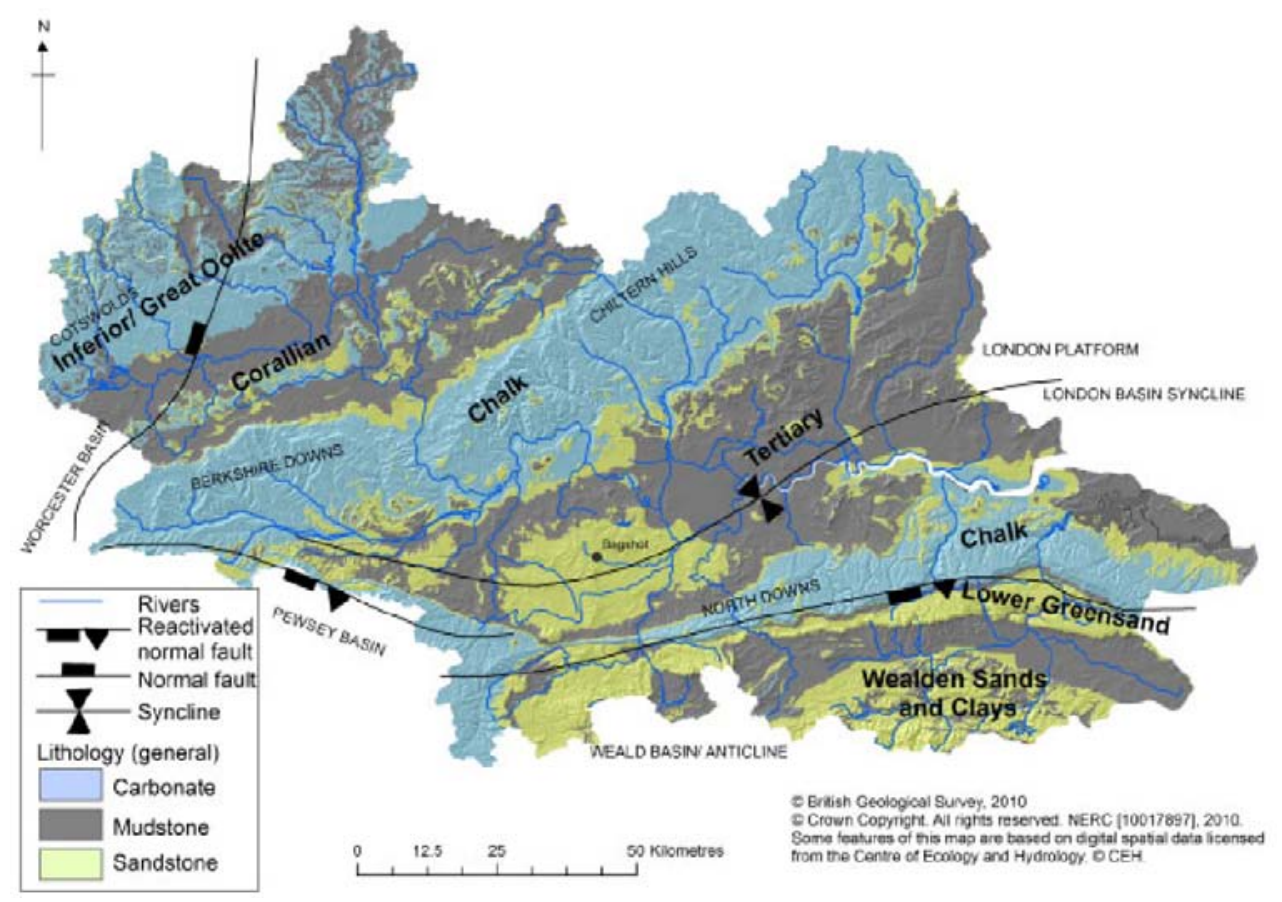

Figure 2. Map showing the geological structure of the Thames basin and disposition of the main sedimentary sequences based on the three predominant lithotypes: carbonates, sandstones, and mudstones 


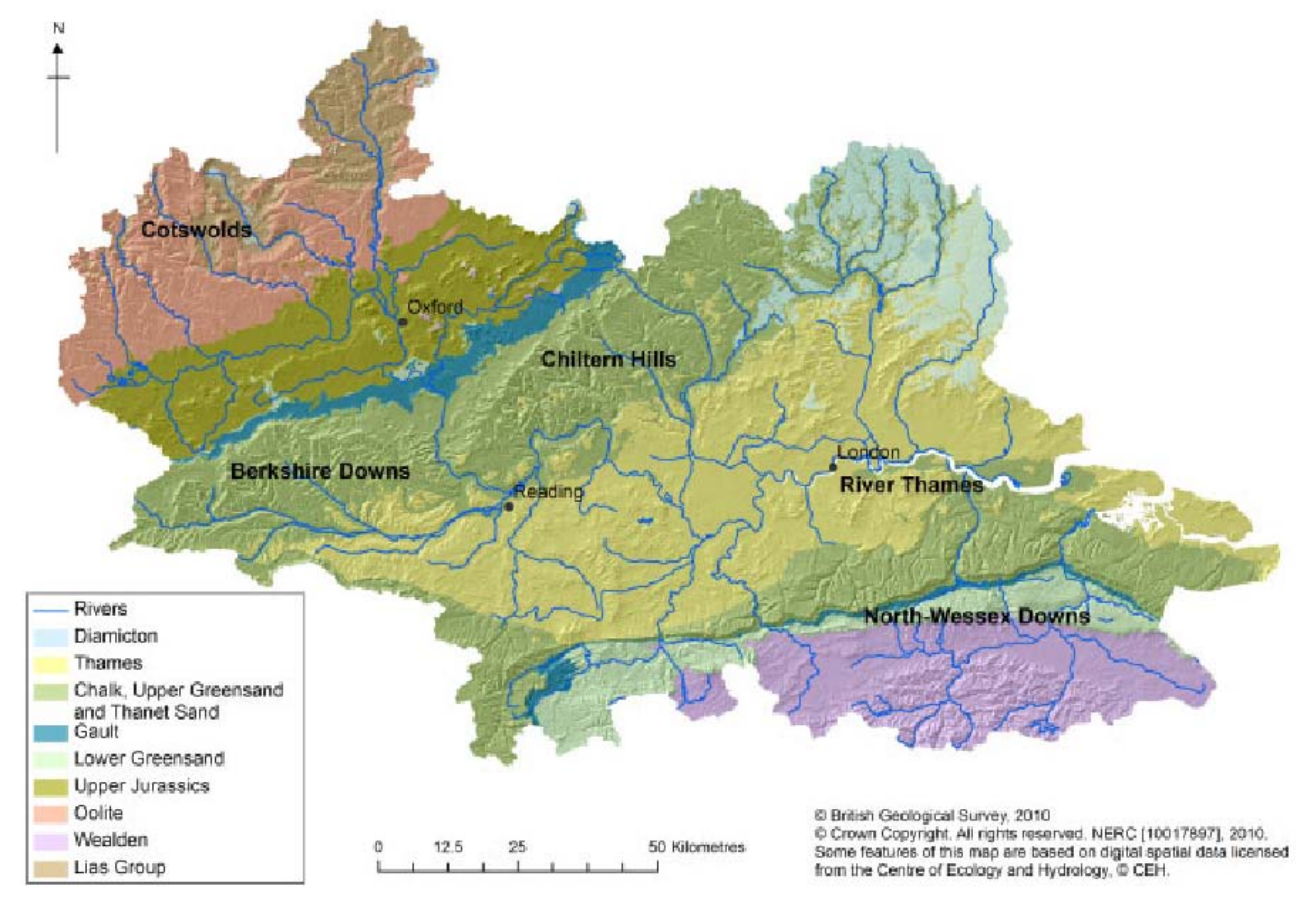

Figure 3. Map showing the distribution of the nine groundwater units across the Thames basin

Figure 3. Map showing the distribution of the nine groundwater units across the Thames basin

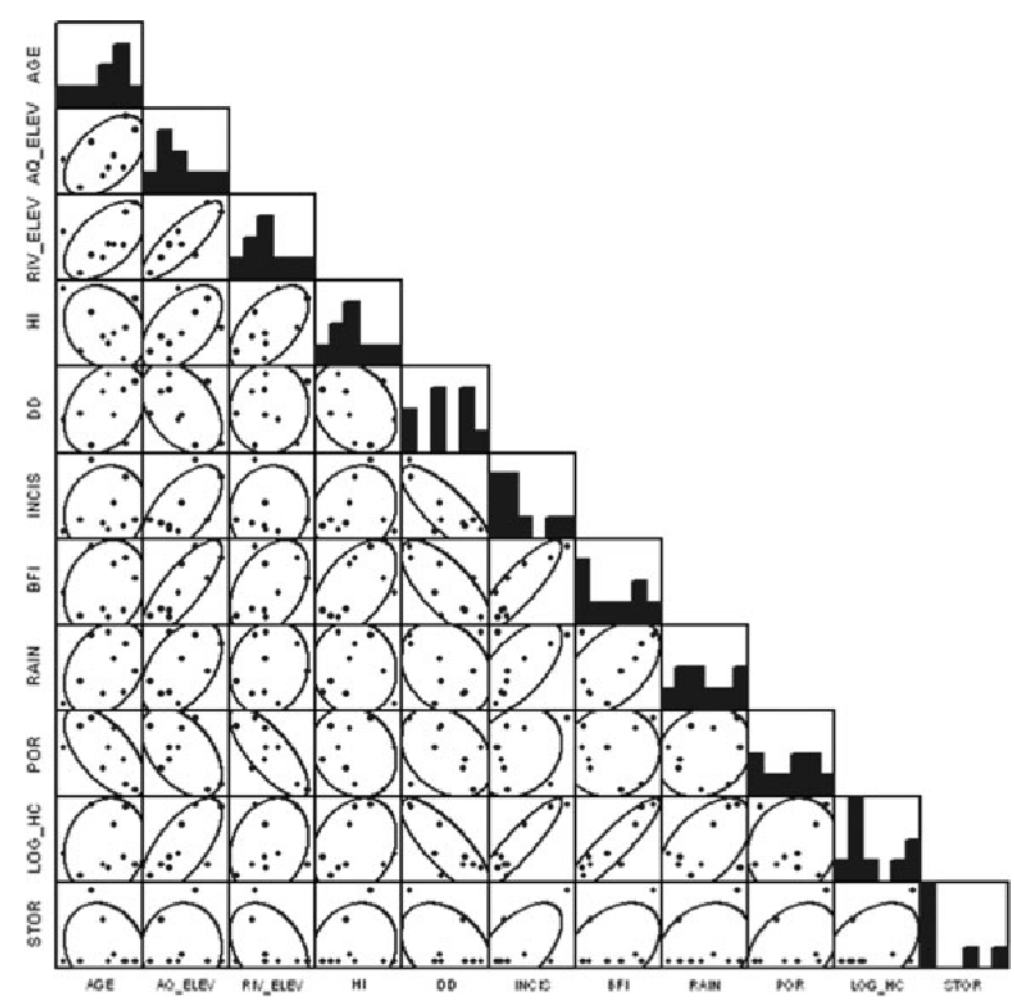

Figure 4. Scatter plot matrix showing scatter plots (with 95\% confidence ellipsoid for the sample) for all pairs of eleven variables and associated frequency histogram for each variable. Where, for a given unit, AGE is the mean age, AQ ELEV is mean elevation, RIV ELEV is the mean elevation of rivers, DD is drainage density, INCIS is incision, RAIN is mean annual rainfall, HI is hypsometric integral of the largest contiguous area within the unit, BFI is an estimate of a representative Baseflow Index, POR is estimated porosity, LOG HC is mean log10 hydraulic conductivity, and STOR is the storativity 
Table I. Description of the main geological and hydrogeological features of the nine hydrogeological units

\begin{tabular}{|c|c|c|}
\hline Hydrogeological unit & Lithological class & Hydrogeological characteristics \\
\hline Diamicton & Superficial clay & $\begin{array}{l}\text { - Non-stratified mix of sand, gravel, and pebble beds set in a } \\
\text { clay matrix, this unit is largely impermeable and acts as a } \\
\text { control on recharge to underlying deposits. }\end{array}$ \\
\hline Thames & Mudstone & $\begin{array}{l}\text { London clay formation dominates the stratigraphy forming a } \\
\text { highly impermeable layer which confines the Chalk group. } \\
\text { - The London clay formation is both underlain and overlain by } \\
\text { variable clay, silt and sand lithologies that give rise to } \\
\text { perched groundwater, none of which form significant } \\
\text { aquifers }\end{array}$ \\
\hline Chalk & Carbonate & $\begin{array}{l}\text { - Principle aquifer in Thames basin, with the largest outcrop } \\
\text { area, locally supporting up to } 70 \% \text { of groundwater } \\
\text { abstractions. } \\
\text { - Chalk is a dual porosity medium with karst features. High } \\
\text { storage within fissures and fractures ensures a steady } \\
\text { groundwater discharge to chalk-streams in addition to } \\
\text { discrete spring inputs. } \\
\text { - Topographical control on transmissivity is evident being high } \\
\text { in valleys and low at interfluves. } \\
\text { - The overlying Thanet sand formation and the underlying } \\
\text { Upper Greensand formation are frequently in hydraulic } \\
\text { continuity with the Chalk group and considered to be one } \\
\text { aquifer. }\end{array}$ \\
\hline Gault & Mudstone & $\begin{array}{l}\text { - Predominantly impermeable unit hydraulically separating the } \\
\text { Upper Greensand formation from the Lower Greensand } \\
\text { group. }\end{array}$ \\
\hline Lower Greensand & Sandstone & $\begin{array}{l}\text { High storage aquifer where inter-granular and fissure flow } \\
\text { results in diffuse groundwater flow to rivers and a steady } \\
\text { groundwater head with minimal seasonality. } \\
\text { - Low residence times and the purity of the sand matrix } \\
\text { combine to provide a fresh groundwater system. }\end{array}$ \\
\hline Upper Jurassics & Mudstone & $\begin{array}{l}\text { - The stratigraphy is dominated by the clays of the Ancholme } \\
\text { group which are highly impermeable and commonly used in } \\
\text { landfill engineering. } \\
\text { - Thin sand and limestone beds of the Corallian, Portland and } \\
\text { Purbeck group, occur in upper sections and form locally } \\
\text { important aquifers with high spring discharge. } \\
\text { - Vertical leakage between the aquifer units and the bounding } \\
\text { aquitards has an important control on groundwater resources } \\
\text { and water quality. }\end{array}$ \\
\hline Oolite & Carbonate & $\begin{array}{l}\text { - Major aquifer with high resource potential particularly where } \\
\text { - } \quad \text { Lonfined. } \\
\text { extensive fracturing and faulting. } \\
\text { - High transmissivities and low storativities result in a very } \\
\text { responsive aquifer capable of discharging large quantities of } \\
\text { groundwater quickly. }\end{array}$ \\
\hline Wealden & Sandstone and mudstone & $\begin{array}{l}\text { - The sandstones and siltstones forming the minor aquifers } \\
\text { comprise discontinuous layers resulting in a multi-layered } \\
\text { system with variable groundwater heads. The groundwater } \\
\text { system is further dissected by faults. } \\
\text { - The two aquifer units are hydraulically separated by the } \\
\text { impermeable Wadhurst clay formation and overlain by the } \\
\text { Weald clay formation. }\end{array}$ \\
\hline Lias & Mudstone & $\begin{array}{l}\text { - Predominantly impermeable strata, where thick mudstones } \\
\text { bound thin limestone and siltstone to form a multi-layered } \\
\text { aquifer. } \\
\text { - The variable lithology provides stratigraphical control on } \\
\text { groundwater flow and the emergence of springs. }\end{array}$ \\
\hline
\end{tabular}


Table II. Geomorphological surface water, and aquifer variables used in nthe study as a function of the nine groundwater units

\begin{tabular}{|c|c|c|c|c|c|c|c|c|c|c|c|}
\hline Unit & $\begin{array}{l}\text { Mean age }{ }^{\mathrm{a}} \\
\text { (Ma) }\end{array}$ & $\begin{array}{l}\text { Av. Unit } \\
\text { elevn. } \\
\text { (m aOD) }\end{array}$ & $\begin{array}{c}\text { Av. River } \\
\text { elevn. } \\
\text { (m aOD) }\end{array}$ & $\begin{array}{c}\text { Hypsometric } \\
\text { integral }\end{array}$ & 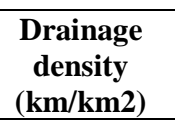 & $\begin{array}{c}\text { River } \\
\text { incision } \\
(\mathbf{m}) \\
\end{array}$ & $\mathbf{B F I}^{\mathrm{b}}$ & $\begin{array}{l}\text { An. Av. } \\
\text { Rainfall } \\
(\mathrm{mm})\end{array}$ & Porosity $^{\mathrm{c}}$ & $\begin{array}{c}\text { Log hyd. } \\
\text { Conductivity }^{3} \\
(\mathrm{~m} / \mathrm{s})\end{array}$ & Storativity ${ }^{c, d}$ \\
\hline Diamicton & 0.4 & 94.03 & 89.61 & 0.51 & 0.88 & 4.42 & 0.56 & 623 & 25.0 & -8.00 & 0.00010 \\
\hline Thames & 45 & 54.68 & 42.17 & 0.27 & 0.96 & 12.51 & 0.36 & 665 & 30.0 & -10.00 & 0.00017 \\
\hline Chalk & 75 & 118.42 & 63.41 & 0.42 & 0.54 & 55.01 & 0.95 & 752 & 31.8 & -3.47 & 0.01620 \\
\hline Gault & 120 & 81.86 & 75.94 & 0.3 & 1.49 & 5.92 & 0.35 & 757 & 25.0 & -9.30 & 0.00010 \\
\hline Lr. Greensand & 135 & 99.59 & 74.79 & 0.34 & 0.95 & 24.8 & 0.80 & 707 & 29.4 & -5.28 & 0.00170 \\
\hline Up. Jurassics & 160 & 82.13 & 73.82 & 0.24 & 1.28 & 8.31 & 0.41 & 644 & 22.0 & -8.30 & 0.00010 \\
\hline Oolites & 165 & 154.89 & 111.82 & 0.36 & 0.56 & 43.07 & 0.85 & 735 & 16.2 & -3.66 & 0.00015 \\
\hline Wealden & 105 & 70.62 & 60.24 & 0.327 & 1.26 & 10.38 & 0.42 & 642 & 20.0 & -9.00 & 0.00950 \\
\hline Lias & 190 & 135.97 & 123.28 & 0.47 & 1.39 & 12.69 & 0.68 & 684 & 15.0 & -9.00 & 0.00010 \\
\hline
\end{tabular}

aWaters (2008).

bNERC (2008). UK Hydrometric Register.

c Aquifer Properties Manual (Allen et al., 1997) and book values (Morris and Johnson, 1967; Freeze and Cherry, 1979; Reeves et al., 2006).

$\mathrm{d}$ Where no data is available for the storativity of clay-dominated units the storativity is set to $1 \mathrm{E}-04$. 
Table III. Pearson correlation coefficients for pairs of variables. Correlations with Pearson correlation coefficients greater than 0.8 or less than -0.8 that are significant at $>\mathbf{9 9} \%$ confidence interval are shown in bold font.

\begin{tabular}{|c|c|c|c|c|c|c|c|c|c|c|c|}
\hline & Mean age & $\begin{array}{l}\text { Av. Aquifer } \\
\text { elevation }\end{array}$ & $\begin{array}{l}\text { Av. River } \\
\text { elevation }\end{array}$ & $\begin{array}{l}\text { Hypsometric } \\
\text { integral }\end{array}$ & $\begin{array}{l}\text { Drainage } \\
\text { density }\end{array}$ & $\begin{array}{l}\text { River } \\
\text { incision }\end{array}$ & $\begin{array}{l}\text { Av. An. } \\
\text { Rainfall }\end{array}$ & BFI & Porosity & $\begin{array}{l}\text { Log- } \\
\text { hydraulic } \\
\text { cponductivity }\end{array}$ & Storativity \\
\hline Mean age & 1 & & & & & & & & & & \\
\hline $\begin{array}{l}\text { Av. aquifer } \\
\text { elevation }\end{array}$ & $\begin{array}{l}0.521 \\
(0.150)\end{array}$ & 1 & & & & & & & & & \\
\hline $\begin{array}{l}\text { Av. river } \\
\text { elevation }\end{array}$ & $\begin{array}{l}0.560 \\
(0.117)\end{array}$ & $\begin{array}{l}0.831 \\
(0.005)\end{array}$ & 1 & & & & & & & & \\
\hline $\begin{array}{l}\text { Hypsometric } \\
\text { integral }\end{array}$ & $\begin{array}{l}-0.204 \\
(0.599)\end{array}$ & $\begin{array}{l}0.576 \\
(0.104)\end{array}$ & $\begin{array}{l}0.593 \\
(0.093)\end{array}$ & 1 & & & & & & & \\
\hline $\begin{array}{l}\text { Drainage } \\
\text { density }\end{array}$ & $\begin{array}{l}0.315 \\
(0.409)\end{array}$ & $\begin{array}{l}-0.421 \\
(0.259)\end{array}$ & $\begin{array}{l}0.035 \\
(0.929) \\
\end{array}$ & $\begin{array}{l}-0.314 \\
(0.41) \\
\end{array}$ & 1 & & & & & & \\
\hline River incision & $\begin{array}{l}0.140 \\
(0.719) \\
\end{array}$ & $\begin{array}{l}0.615 \\
(0.078) \\
\end{array}$ & $\begin{array}{l}0.073 \\
(0.853) \\
\end{array}$ & $\begin{array}{l}0.193 \\
(0.618) \\
\end{array}$ & $\begin{array}{l}-806 \\
(0.009) \\
\end{array}$ & 1 & & & & & \\
\hline Av. an. rainfall & $\begin{array}{l}0.341 \\
(0.369) \\
\end{array}$ & $\begin{array}{l}0.460 \\
(0.213) \\
\end{array}$ & $\begin{array}{l}0.129 \\
(0.741) \\
\end{array}$ & $\begin{array}{l}0.019 \\
(0.961) \\
\end{array}$ & $\begin{array}{l}-0.252 \\
(0.513)\end{array}$ & $\begin{array}{l}0.642 \\
(0.062)\end{array}$ & 1 & & & & \\
\hline BFI & $\begin{array}{l}0.213 \\
(0.528) \\
\end{array}$ & $\begin{array}{l}0.802 \\
(0.009) \\
\end{array}$ & $\begin{array}{l}0.408 \\
(0.276) \\
\end{array}$ & $\begin{array}{l}0.545 \\
(0.129) \\
\end{array}$ & $\begin{array}{l}-0.722 \\
(0.028) \\
\end{array}$ & $\begin{array}{l}0.861 \\
(0.003) \\
\end{array}$ & $\begin{array}{l}0.489 \\
(0.181) \\
\end{array}$ & 1 & & & \\
\hline Porosity & $\begin{array}{l}-0.775 \\
(0.068)\end{array}$ & $\begin{array}{l}-0.478 \\
(0.182)\end{array}$ & $\begin{array}{l}-0.678 \\
(0.018) \\
\end{array}$ & $\begin{array}{l}-0.107 \\
(0.397)\end{array}$ & $\begin{array}{l}-349 \\
(0.397)\end{array}$ & $\begin{array}{l}0.105 \\
(0.607)\end{array}$ & $\begin{array}{l}0.030 \\
(0.661)\end{array}$ & $\begin{array}{l}-0.084 \\
(0.966)\end{array}$ & 1 & & \\
\hline $\begin{array}{l}\text { Log hydraulic } \\
\text { conductivity }\end{array}$ & $\begin{array}{l}0.149 \\
(0.702) \\
\end{array}$ & $\begin{array}{l}0.680 \\
(0.044) \\
\end{array}$ & $\begin{array}{l}0.218 \\
(0.573) \\
\end{array}$ & $\begin{array}{l}0.278 \\
(0.469) \\
\end{array}$ & $\begin{array}{l}-0.811 \\
(0.008) \\
\end{array}$ & $\begin{array}{l}0.910 \\
(0.001) \\
\end{array}$ & $\begin{array}{l}0.548 \\
(0.127) \\
\end{array}$ & $\begin{array}{l}0.888 \\
(0.001) \\
\end{array}$ & $\begin{array}{l}0.111 \\
(0.710) \\
\end{array}$ & 1 & \\
\hline Storativity & $\begin{array}{l}-0.200 \\
(0.607) \\
\end{array}$ & $\begin{array}{l}0.030 \\
(0.939) \\
\end{array}$ & $\begin{array}{l}-0.380 \\
(0.312) \\
\end{array}$ & $\begin{array}{l}0.061 \\
(0.877) \\
\end{array}$ & $\begin{array}{l}-0.377 \\
(0.317) \\
\end{array}$ & $\begin{array}{l}0.593 \\
(0.092) \\
\end{array}$ & $\begin{array}{l}0.249 \\
(0.518) \\
\end{array}$ & $\begin{array}{l}0.424 \\
(0.256) \\
\end{array}$ & $\begin{array}{l}0.294 \\
(0.334) \\
\end{array}$ & $\begin{array}{l}0.429 \\
(0.249) \\
\end{array}$ & 1 \\
\hline
\end{tabular}

